\title{
Mothering in a foreign language: Silent and/or multilingual mothers in Dalia Staponkutè's The Silence of the Mothers
}

\author{
Eglè Kačkutè ${ }^{1}$ \\ Vilnius University, Gender Studies' Centre, Didlaukio str. 47, LT-08303 Vilnius, Lithuania
}

\section{A R T I C L E I N F O}

Available online 27 June 2015

\begin{abstract}
S Y N O P S I S
This article analyses the figure of the silent mother portrayed in Dalia Staponkute's essay The Silence of the Mothers partly based on many Lithuanian women who, after the fall of the Berlin wall, emigrated to Western countries through marriage and are often negatively stereotyped as passive, silent, sexualized and unintelligent. I argue for a more complex interpretation. The silent mother's inability to embrace the language of the host country originates in her trauma associated with the complicated history and gender culture of her native, recently decolonized post-Soviet Lithuania. Conversely, the multilingual mother, as also portrayed in Staponkutè's essay, embodies the potential to overcome the trauma and alleviate the pain of motherly silence. The mechanism of shuttle translation evoked in the essay enables her to overcome her personal and cultural trauma as well as create and sustain an embodied linguistic bond with her children.
\end{abstract}

(c) 2015 Elsevier Ltd. All rights reserved.

\section{Introduction}

In the last ten years Lithuania along with the rest of the post-Soviet world - the other Baltic states, Central and Eastern Europe, the Caucasus, and Central Asia - has been usefully theorized as a postcolonial space (Baločkaitè, 2008, 2009; Chioni Moore, 2006; Kelertas, 2006). For over a hundred years all of the countries in the area, Lithuania not being an exception, were subject to "often brutal Russian domination (styled as Soviet from the 1920s on)" (Chioni Moore, 2006: 17). Although Lithuania was only annexed to the Soviet Union in 1940, having enjoyed a brief period as an independent state between the wars, from 1795 until 1918 it was subjected to the rule of Imperial Russia (Kiaupa, 2002). Two decades into its newly created democracy, contemporary Lithuania displays many qualities recognizable as postcolonial, such as a transition to new societal and economic principles and practices based on a Western European model, and social, emotional and ideological confusion (Baločkaitè, 2008).

One of the most striking features of post-Soviet decolonization is the opening of the borders, resulting in significant numbers of formerly sedentary and contained postcolonial subjects setting out to explore the world beyond the Iron
Curtain. Women have been extremely active in seizing this opportunity, not only to discover new territories and to join the ranks of short-term migrants, but also to permanently relocate to what was and still is seen as a better world, and one of the means for this has been international marriage. Rasa Baločkaitė argues that migration through marriage from the post-Soviet space is often driven by economic reasons, although she admits that "it is very difficult to determine when such marriages are built on genuine feelings and when they are motivated by the desire to move to an affluent country" (Baločkaitė, 2009). I would also suggest that the two are not mutually exclusive. As a result of these developments, there is a rapidly growing corpus of exile literature written in Lithuanian and published in Lithuania and often by women. It reflects on the postcolonial migrant experience, including specifically female migrant experiences. However, fiction exploring the experience of exile through marriage is scarce (Kelertas, 2006; Kolevinskienè, 2012; Litvinskaitė, 2013; Satkauskytė, 2011). In this article I shall focus on the only existing text in the Lithuanian language dealing with the subject Motinu tylejimas [The Silence of the Mothers] by Dalia Staponkute (first published in 2003 in one of the most widely read cultural weeklies in the country, "Šiaurès Atenai"). ${ }^{2}$ At the turn of the century, which 
coincided with Lithuania's breaking free from the Soviet Union (Lithuania announced the restoration of independence on 11 March, 1990), intellectualized personal essays became the dominant genre in Lithuanian literature referred to by literary critics as the "essay". ${ }^{3}$ Writing for an international academic audience in English, Lithuanian literary scholar Dalia Čiočytė describes it as follows: "In Lithuanian, the term 'essay' is used to define a genre that balances between fiction and journalism: critical writing with elements of fiction: 'critical essay' and 'literary essay' (most closely related to the term 'personal essay' in English)" (Čiočytè, 2011: 242). "Critical" in this case means academic and "literary" means non-fiction, emphasizing its belonging in the realm of creative writing.

Dalia Staponkutè's autobiographical essays are part of emerging contemporary Lithuanian exile writing. Her texts offer a personal, philosophical, poetic, and often melancholic reflection on the state of a migrant Lithuanian woman and mother. Staponkutè was born in 1964 in Šiauliai. After graduating from the School of Philosophy of Saint Petersburg State University (at the time, Leningrad State University) she taught philosophy at the University of Šiauliai for several years before moving to the Greek part of Cyprus in 1989, with the intention of marrying a Greek Cypriot man she had met during her studies in Saint Petersburg. In Cyprus, she started translating from English, Russian and later from Modern Greek to Lithuanian (Nikos Kazantzakis) and from Lithuanian to Greek (Lithuanian poet Sigitas Parulskis' work). Staponkutè says that her translation work and constant travelling between her "two homelands" have led to her research in comparative literature, translation studies and made her discover Mikhail Bakhtin's and Alphono Lingis's philosophies of language. ${ }^{4}$ Having completed a PhD on travel writing and translation, Staponkute teaches translation theory and travel writing at Cyprus State University and elsewhere. Now a divorced mother of two adult daughters, she lives in Nicosia (Cyprus), works internationally, and continues to write nonfiction in Lithuanian and academic research in English. Her monograph Exultant Forces of Translation and the Philosophy of Travel of Alphonso Lingis was published in 2014 in New York (Staponkutè, 2014a). Staponkutè's essay The Silence of the Mothers later featured in her collection of essays Lietumi prieš saule [Rain Versus Sun] is the only example of Lithuanian exile writing dealing with the complex issue of international motherhood (Staponkute, 2007)..$^{5}$ In this text she explores the state of mothers who do not share the same linguistic and cultural environment with their children. For Staponkutè, silent mothers are "mothers who are unable to talk to their children in their native language" (Staponkutè, 2009a), which suggests the refusal to transmit the native tongue not through design but by circumstance. In the following section I shall discuss Staponkutè's portrayal of such women in the context of female post-Soviet migration from Lithuania, which serves as a cultural, social and critical background for the character of the silent mother in contemporary Lithuanian exile writing. The Silence of the Mothers is a subjective philosophical reflection on migrant mothers' lives in a meditative, almost poetic vein, informed by Staponkutè's personal experience of international and multilingual mothering and her extensive reading in philosophy and critical theory. It is a personal essay, a nonfiction text, though observing some of the rules of fiction and storytelling, making use of different literary devices and enjoying a distinctive voice. It is also generously dotted with theoretical references and is structured as a classical Montaigne's essay.

My aim in this article is to analyse the perplexing figure of the silent mother portrayed in Staponkutè's essay. This figure is partly based on many Lithuanian (and by extension Eastern European) women who, after the fall of the Berlin wall, emigrated to Western countries through marriage and are often negatively stereotyped as passive, silent, sexualized and unintelligent. However, I will argue for a more complex interpretation. In the first section of the article, entitled "Traumatic and traumatizing silence", I offer a critique of the stereotypically negative portrayal of marriage exiles from postSoviet Lithuania and argue that the figure of the silent mother in Staponkutè's text can be read as marked by personal and cultural trauma: the personal trauma deriving from her silence in relation to her children; and the cultural trauma being a result of her own national and historic background that is Lithuania's traumatizing history in the twentieth century and the gender culture of post-Soviet Lithuania. I also suggest that her inability to adopt and appropriate the language of the host country could be a result of the Lithuanian national discourse on motherhood and the role attributed to mothers in the Lithuanian cultural imagination, which puts the responsibility of safeguarding the Lithuanian language and, by default, the Lithuanian state, primarily on the shoulders of mothers. This might be one of the reasons why Lithuanian migrant mothers are particularly subject to traumatic and traumatizing silence vis-à-vis their children. In the second part of the article entitled "Obtaining a voice" I focus on Staponkutè's alter ego multilingual mother who carries something of a silent mother within her and also appears to be traumatized to a degree by linguistic and cultural distance from her children. Conversely though, the multilingual mother, as portrayed in Staponkute's essay, embodies the potential to overcome the trauma and alleviate the pain of motherly silence. Staponkutè's text suggests that the multilingual mother's efforts to learn the language of the host country, whilst maintaining the possibility to communicate with her children in both her native and the language of the place in which they live, enable her to overcome her personal and cultural trauma and embark on a new beginning as a woman and mother.

As a special contribution to wider interests of Women's Studies International Forum and the current Special Issue of the journal, the article introduces writing from the Lithuanian diaspora and sheds light on Lithuanian cultural history in which mothers played a crucial role in preserving Lithuanian language in the face of Soviet efforts to downgrade or eradicate it. In a wider context of exile, the article explains the mother's role in passing the tongue of the motherland to the children and explores the role of language in helping migrant women to overcome personal and cultural traumas of the native country's troubled history.

The theoretical framework of my analysis consists of two main sources: Cathy Caruth's psychoanalytic trauma theory and Julia Kristeva's notion of the semiotic chora that is part of her psycholinguistic interpretation of language. Caruth's theory developed from Freud's work on trauma, including his essay Beyond the Pleasure Principle in which he describes and analyses experiences of the veterans of World War I, consisting of repetitive dreams of the battlefield, bringing back vivid memories of violent scenes they had witnessed during the 
war (Caruth, 1995). Caruth's trauma theory embraces the idea that trauma is something that cannot be grasped, contained or understood and that it is essentially linked with memory and repetition. It also rests on the belief that putting traumatic past experiences into stories and sharing them has a healing effect in that it creates a distance between the experience and the one who experienced it. Furthermore, it bears witness to the traumatic and tragic events drawing the survivors and the listeners into a community, which gives a certain meaning to the suffering of the survivor. Caruth's idea that trauma is related to the way in which the mind experiences and processes the passing of time is important in my analysis of the trauma of the silent mother. Caruth explains that trauma originates from the fact that the mind registers a dangerous experience with a delay, which then creates difficulty processing it, thus producing the effect of a missed experience and causing damage to the psyche (Caruth, 2001). I shall use this structure to understand and explain how the exiled mother's initial silence in relation to her children, due to her own efforts to learn the language of the host country, leads to her psychological injury.

Kristeva's psychoanalytic theory of language is centred on the speaking subject and differentiates between two interacting processes that constitute language and produce meaning - the symbolic and the semiotic (Kristeva, 1980, $1984,1986)$. The symbolic process represents formal aspects of language - grammatical and social constraints - that are associated with the paternal function. The semiotic process is related to the maternal and is linked with the primary drives that are all amassed in the semiotic chora (receptacle) - a notion that Kristeva borrows from Plato and theorizes as part of linguistic subjectivity. Kristeva describes the chora as:

An essentially mobile and extremely provisional articulation constituted by movements and their ephemeral stasis ... Neither model nor copy, the chora precedes and underlies figuration and thus specularization, and is analogous only to vocal and kinetic rhythm.

[Kristeva, 1986: 94]

The semiotic chora is the aspect of language that is closely related to the human body and the oral dimension of linguistic expression. It precedes meaning and yet participates in the construction of a human being as a social subject, because the chora is an entity through which the maternal body inscribes social and family structures in the developing subject by means of pre-linguistic communication, consisting largely of rhythmic vocal utterances. However, in order for language to produce meaning, the semiotic flow - the heterogeneous play of the primary drives within the chora - has to be disrupted. Once the subject enters the symbolic order, the chora is more or less repressed and manifests itself mostly as silences, disruptions and absences. What is particularly important for my analysis here is that the remaining function of the chora in a fully developed subject is maternal continuity that, according to Kristeva's theory, guarantees identity (Kristeva, 1986).

In the last decade Lithuanian exile literature has enjoyed growing academic critical interest. ${ }^{6}$ Violeta Kelertas reads Lithuanian emigration narratives in the light of postcolonial theory. She observes that "current prose fiction [...] does not lack the energy to articulate the past decade's collisions with the Western world" (Kelertas, 2006: 452). She looks at the work of two women writers, Jurga Ivanauskaite and Zita Čepaitè, reflecting on their first European trips after the opening of Lithuanian borders and their initial encounters with the "West". Kelertas concludes that the alter ego characters in both authors' texts operate "only in stereotypes about the Other" (Kelertas, 2006: 454) and through their travels "try unsuccessfully to reconcile two essentially incompatible things - a sexual quest and an exalted spiritual state, combined with an attraction to the exotic" (Kelertas, 2006: 454). Literary scholar Dalia Satkauskytė reads contemporary Lithuanian exile writing against Homi Bhabha's notions of hybridity and "in-between". ${ }^{7}$ She evokes the most iconic definition of hybridity inscribed in Bhabha's statement: "the truest eye may now belong to the migrant's double vision" (Bhabha, 2004: 8), which, in her view, puts more value on belonging to two cultures, languages and identities than just one. The notion of "in-between" describes a form of identity formation in the contemporary context of multiple subject positions defined by Bhabha as "processes that are produced in the articulation of differences" (Bhabha, 2004: 2), including linguistic differences. "In-between" is a productive space, which allows for a new identity to be negotiated and constructed out of multiple national and cultural subject positions and characteristics.

However, Satkauskyte argues that Bhabha's notion of hybridity is inoperative in recent Lithuanian exile writing, because the latter tends to posit stable markers of identity such as language, place, history and national culture as the main points of identification through the language of writing (Lithuanian), cultural and literary references to Lithuanian literature and the symbolic function of place. Lithuanian cities, usually Vilnius, are figured in it as home that generates feelings of longing as well as belonging. Satkauskyte embraces a critique of Bhabha's theory offered by the Danish postcolonial theorist, Sten Pultz Moslund, who labels Bhabha's hybridity celebratory and believes that there is no one stable identity and no definable hybridity to counterbalance it. One can only talk of different speeds of hybridization. Satkauskytė concludes that recent Lithuanian exile literature falls into the category of slow hybridization, which is still hardly noticeable, mainly because post-Soviet migration is only approximately twenty years old and the writers in question were all adults at the time of leaving Lithuania. Nonetheless, Satkauskytė identifies Dalia Staponkutè's prose as being marked by the sense of "in-between", due to the relative longevity of her life abroad (half her life), her international marriage and children who belong to a different cultural and linguistic space than their mother. Satkauskytè suggests that, contrary to the positive hybrid identity advanced by postcolonial theory, which implies belonging to two cultures at the same time and in equal measure, Staponkutè's textual alter ego finds herself belonging neither back home nor in the adopted host country and culture (Satkauskytè, 2011). ${ }^{8}$ Literary scholar Žydronė Kolevinskienė shares such a view. She coins the term "imprisoned identity" to describe contemporary Lithuanian female exile subjects and summarizes their trajectory as follows: "They leave their country, their home that has become alien to them, but the new country is not home either" (Kolevinskienè, 2012: 29). ${ }^{9}$ I support and further develop this reading in this article. 


\section{Traumatic and traumatizing silence}

In his essay "Is the Post- in Postcolonial the Post in PostSoviet? Towards a Global Postcolonial Critique", Chioni Moore describes two types of compensatory behaviour characteristic of post-Soviet postcolonial populations: "an exaggerated desire for authentic sources" and mimicry, driven by the "long simultaneously exalted and withheld" postcolonial desire of the dominant cultural form, which in the post-Soviet world is fixated not on the cultural form of the former colonizer, but on the Western world (Chioni Moore, 2006: 20-21). The exaggerated desire for authentic sources in Lithuania manifests itself, among other things, as a strong investment in the national language (Lithuanian) both by the state and by individuals: maintaining, safeguarding, cleansing and protecting it from foreign influences as well as ensuring its dominant and superior status in relation to other languages spoken in the country (Pavlenko, 2008). Conversely, from the point of view of a post-Soviet subject, international marriage can be seen as a powerful expression of mimicry. For Lithuanian women marrying Western men and moving to a Western country and society, where they are expected to mimic and adopt the local gender culture, may be one of the means to fulfil the postSoviet desire of becoming a "real" Western woman.

Gender studies have convincingly demonstrated that gender is defined, constructed and produced through gendering practices that include a set of behaviours and everyday practices, such as dress, choice of professional and house work, body language, and social interactions, that mark an individual as belonging to one gender or another (Butler, 1990; Lorber, 1994). As gender norms and expectations vary from culture to culture, even if relatively insignificantly in the Western world, it is only understandable that some exiled subjects choose to adapt to, rather than transgress, the dominant gender paradigm in their new environment. Fulfilling the desire to become "real" Western women for Lithuanian marriage exiles involves performing and mimicking women of the countries they live in, adopting a different gender culture and role of a woman, wife and mother that is not necessarily fully familiar or acceptable in post-Soviet Lithuania. For example, being a stay-at-home fulltime mother has been and remains uncommon in Lithuania, not only because it is usually a financial necessity for women to work, but mostly because for fifty years it was prevented by the Soviet law. Therefore, in the early days of independence stayat-home mothering was and is still largely seen as a desirable identity for women in Lithuania. Together, both compensatory mechanisms - safeguarding the Lithuanian language and becoming a "real" Western woman - have a peculiar hold on postcolonial, post-Soviet Lithuanian women in exile, who find themselves caught in the grip of both those forces that lay conflicting claims on their lives and identities. As Lithuanian mothers, they are implicitly expected to pass on their language to their children and thus ensure its continuation; as women and wives, they are forced to abandon part of their identity and become other, adopt a foreign gendered identity, which includes a foreign linguistic identity too. As I will show, the identity of the silent mother, as featured in Staponkute's essay, offers an interesting example of how these forces play out on an individual level.

Lithuanian sociologist Rasa Baločkaitè paints a rather grim picture of Lithuanian marriage exiles' lives in the US, equating them to illegal immigrants and arguing that, in their host country, they are treated with humiliation and contempt: "Many of these women are restricted by linguistic and cultural differences, socially isolated and entirely dependent on their spouses" (Baločkaitè, 2009). The figure of a silent mother in Staponkutè's essay is clearly based on this negative stereotype of Lithuanian women, whose postcolonial desire is fixated on a foreign (Western) man, and whose identity is fully predicated on the powerful other, whose individuality is silenced, and who fit rather comfortably with the media constructed image of them as "iconic representations of eternal femininity" (Baločkaitè, 2009). In The Silence of the Mothers, the silent mother is most vividly personified by a long legged, long haired Lithuanian blond married to a Greek husband. ${ }^{10}$ The couple are said to live in "mystical linguistic circumstances: their children don't speak Lithuanian; the mother speaks no Greek though she's picked up a smattering of English..." (Staponkutè, 2009a), which she presumably uses to communicate with her husband and children. What is surprising in this set-up is not the fact that the children do not speak any Lithuanian - they, after all, live in Greece - but that the mother does not speak any Greek.

This is, of course, an extreme, hyperbolized and almost caricature portrayal of an international marriage of a Lithuanian woman and a Southern European man, which is used firstly to highlight the negative stereotype of female marriage exiles, and secondly to point out the gendered nature of their exile. Through such a stylized example of a mother failing to adapt to the culture of her family, Staponkute reflects on the cultural phenomenon of women's exile from Eastern Europe and possibly other countries with complicated histories and gender regimes tied to those histories that are exceedingly different from the ones found in the countries of the so-called "Old Europe". The use of stereotype is probably unconscious here and functions as a distancing device. It creates a qualitative gap between uneducated, possibly lower class marriage immigrants (as theorized by Baločkaitè) and Staponkutè herself as an educated, intellectual marriage exile reflecting on her own experience in a literary and thus, by definition, privileged space. However, through the figure of Staponkute's silent mother, I aim to carry out a more sympathetic reading of the predicament of post-Soviet Lithuanian marriage exiles. Furthermore, as I will demonstrate, the multilingual mother in Staponkutè's text that comes across as her alter-ego also has something of the silent mother in her. This implies that the state of silent mothering transcends class stratification, especially considering a relative absence of the class system in Soviet Lithuania, due to the Soviet system, a uniform poverty of the country that was particularly severe at the time of the break away from the Soviet Union, and that no class is immune to postcolonial desire.

Staponkutè's text suggests that mothers who do not speak their first language to their children suffer painful emotional losses that can be experienced as traumatizing. Letting a foreign language slip in between the mother and her children interferes with what the narrator sees as a vital and single entity - mother, place and language. Even partial disintegration of this menaces the integrity of the mother's identity. Staponkutė writes:

Mother, place, and language are organically intertwined elements, parts of the chain of life that, once broken, can 
never be forged anew. [...] by allowing a foreign language to exist between her and her child, she is doomed to a stony silence.

[Staponkutè, 2009a]

Her point is that it is somehow the mother's fault or failing (or at least the mother experiences it as such) that she allows the menacing otherness of a foreign language to come between her and her offspring and is therefore punished with silence that is stony or lethal. However, as far as the mother is concerned, the fatal opening up to the menacing other (the foreign language) comes along imperceptibly, without the slightest warning of the threat it constitutes, and it is that gap between the danger and its perception that signifies traumatic damage:

Lithuanian women and men, single and married, migrating perennially or because they are on some sort of mission, having landed in their chosen, or promised, no-man's-lands [...]. For the majority of these people, the sudden change in their relationship to their mother tongue and their assimilation into a different linguistic environment seem to proceed quite painlessly, leaving only a faint trace, like a mild rash that comes from rubbing skin against stubble. In this process, time and place become not foes but dependable coconspirators. But the new linguistic space and the time lived inside it present a real threat to the dialogue between mother and child - to its mystery, content, and intimacy (emphasis mine).

[Staponkutè, 2009a]

Here, new migrants, especially new migrant mothers, seem to fall prey to a sort of fallacy. They think, erroneously, that the assimilation into the new linguistic environment, the taming of the new language and place, both processes that by definition span over a period of time, is the right way forward, and something to be trusted. However, it turns out to be their worst enemy and even threatening their identity as mothers.

In her article entitled "Parting Words: Trauma, Silence and Survival", Caruth revisits Freud's seminal text on trauma and explores the link between the symptoms of trauma survivors and the nature of Freud's "fort-da" game and concludes that the drive for death inherent in post-traumatic symptoms restructures itself into the drive for life implicated in the creative repetitiveness of the game. The crucial connection lies in the way traumatic memories are processed by the survivor and what constitutes trauma itself, which Caruth defines as follows:

What causes trauma, then, is an encounter that is not directly perceived as a threat to the life of the organism but that occurs, rather, as a break in the mind's experience of time. [...] It is not the direct perception of danger, that is, that constitutes the threat for the psyche, but the fact that the danger is recognized as such one moment too late.

[Caruth, 2001: 10]

Trauma is thus intrinsically linked with the passing of time in the face of danger and the mind's failure to register the experience as potentially damaging. Staponkutè's silent mother delves into the new linguistic environment, ignoring the mild irritation that accompanies her altered linguistic existence, and falls short of recognizing what the narrator calls "the new linguistic space and the time lived inside it" as dangerous until too late, until the time of the fatal break occurs, inflicted by her giving her children away to the foreign language-place, sacrificing them to the "place-cannibal":

The migrant mother often ends up sacrificing the child to the foreign place, which gradually replaces the mother and, like an authoritative guardian of language and culture as well as a strict and systematic teacher, welcomes its new "pupil".

[Staponkutè, 2009a]

The vital equation mother-language-place is partially disintegrated and it is the mother who is no longer in it. By failing to recognize the foreign language as a threat, Staponkutè's silent mother ends up experiencing and surviving her own death. The trauma or, to use Caruth's terms, the break in the psyche brought about by the foreign language, is poignantly imagined in the essay as a tragic split:

Children born outside the space of their mother's native language or their mother's homeland disavow their mothers as soon as they learn to walk. Children, even little pip-squeaks, manage to jump across the chasm separating their mothers from their locale with such alacrity that the mother from a strange land ends up stranded on the other side before she can even manage a gasp.

[Staponkutè, 2009a]

The combination of the mother's native language and homeland (mother-language-place) in Staponkutè's text is evocative of and plays the role of Kristeva's notion of semiotic chora, which is the realm of language that is tied to the maternal body, the structure that makes it possible to articulate the mother's embodied linguistic relation to the child. ${ }^{11}$ Characterized by "energy charges", "rupture and articulation", and "vocal or kinetic rhythm", chora is a pre-linguistic bond between the mother and her child, which paradoxically constitutes them both as distinct subjects forever linked by the common linguistic experience that precedes discourse and meaning - the experience essentially grounded in the body:

The oral and anal drives, both of which are oriented and structured around the mother's body, dominate this sensomotor organisation. The mother's body is therefore what mediates the symbolic law organising social relations and becomes the organising principle of the semiotic chora.

[Kristeva, 1984: 27]

The semiotic chora is what helps construct the subject in its emotional socialization and is essentially dependent on the mother's embodied linguistic instruction and presence.

What cuts the mother off from her child and therefore traumatizes her in Staponkute's essay is the absence of the somatic-linguistic reality of the place, which had put the mother into existence as a subject and which potentially can provide her with the life-giving juices she needs in order to nurture her own offspring. References to suckling, evoked together with land and language, support this idea: "Surrounded by the echoes' fishtail rhythms, all hopes of suckling the child on its mother tongue come to nothing" (Staponkute, 2009a). Explicitly womb-like images such as "the 
new linguistic space and the time lived inside it", "the space of their mother's native language" and the "locale" of the mother's linguistic and cultural surroundings are used to signal her inability to mother without their sustenance. It is the "locale" and/or the body of the child's native language and land that take up the role of the nurturing and structuring chora. Therefore, the children of the silent mother do not seem to suffer too much. It is they who disavow and jump over the linguistic and the cultural barrier. They are active agents who make linguistic and cultural choices and are supported by the "locale", whereas the passive mother remains stranded, cut off and alone.

Throughout Staponkutè's essay the silent mother is portrayed as pathologically unhappy. Her inner world is said to be "turned into permafrost", she "feels a piercing nostalgia", her "every step is marked by sacrifice and loss", etc. She is unable to connect emotionally with the people in her immediate environment:

"Mummy, are you by any chance a mummy?" mocks the snotty child of a Lithuanian mother and a Greek father while she, during a lively Greek conversation, keeps strangely mum.

[Staponkutè, 2009a]

Here, the silent mother is portrayed as absent from her family life, unable to join in the conversation with her children and husband, separated by an invisible wall, and remains a mere speechless and powerless spectator of the family performance in which she plays no role, or rather becomes an object of ridicule. Such behaviour can be read as symptoms of post-traumatic stress disorder, which may include emotional numbing, feelings of estrangement, avoidance of stimuli evocative of the traumatic event, and amnesia, the inability to reconstitute important aspects of the trauma (Caruth, 1995; Gailienè, 2008). Staponkutè's silent mother seems to suffer from all of these symptoms, including linguistic amnesia of her native Lithuanian.

Psycholinguist Anneta Pavlenko claims that people's linguistic choices are profoundly influenced among other things by personal history of trauma, stress, and violence and that they are significantly linked with people's identities. She writes: "The languages we speak or refuse to speak have a lot to do with who we are, what subject positions we claim or contest, and what futures we invest in" (Pavlenko, 2005: 223). Pavlenko provides many compelling examples of people who distance themselves from one language or another, in order to liberate themselves from painful and/or traumatic experiences associated with and lived through in that language media. Considering that language rejection, attrition and loss can be emotionally motivated, I would argue that Staponkute's silent mother's bid to remain silent in her native tongue may be read in the light of trauma to do with her national and gender identity.

Up until the restoration of independence in 1990, Lithuania was always, with the exception of a thirty-year period between the two wars, either occupied by a foreign force or formed joint states with neighbouring countries. During the twentieth century, Lithuania changed hands three times, one repressive regime succeeding another, and was subjected to the Soviet system for half of that century. Psychiatrist Danute Gailienè argues that there is a direct link between this history and the fact that contemporary Lithuanian society suffers from extremely poor psychological health (Lithuania's suicide rates top global charts). She suggests that the entire contemporary Lithuanian population have been similarly affected by Soviet and/or Nazi repressions, irrespective of whether they or their family members were direct victims of violence or not (Gailienè, 2008). Gailienè argues that Lithuania's history of the last century qualifies as traumatizing. From 1940 to 1941, Lithuania was occupied by the Soviet troops for the first time and the first Soviet mass deportations to Siberia started on June 14,1941 . That year on 22 June, Nazi Germany declared war on the Soviet Union and the Nazi occupation of Lithuania began and lasted until 1944. The Holocaust in Lithuania developed monstrous proportions - entire shtetls (small towns with large Jewish populations) were emptied by German troops and Lithuanian collaborators sometimes in the space of just several hours during the night. More than 280,000 Jews or $95 \%$ of the Jewish population in Lithuania lost their lives (Davoliūtè \& Balkelis, 2012). In 1944 the second and final Soviet occupation began, but a bloody armed resistance movement continued until as late as 1953. May 22-23, 1948 saw the biggest wave of deportations from Lithuania with over 40,000 people deported to Siberia almost overnight. During the three occupations that lasted only fifty years, Lithuania lost approximately $33 \%$ of the country's population. From 1940 until 1953 as many as 12,000 people were deported, sentenced to death, jailed, killed for political reasons or forced to emigrate (Davoliūte \& Balkelis, 2012; Gailiene, 2008). One of the reasons why this succession of the tragic historic events has been so damaging is the absence of any relevant public discourse around them. The Holocaust was not appropriately condemned during the Soviet times and Lithuania as a state and a nation still struggles to come to terms with the devastating event and especially its role in it. It was only after the restoration of Lithuania's independence in 1990 that the scope of the harm inflicted by the totalitarian and repressive Soviet system began to be evaluated (Davoliūtẻ \& Balkelis, 2012; Gailiené, 2008).

Moreover, neither of those regimes, especially the Soviet, was particularly sympathetic to women. The historian Dalia Leinartè's research shows how the Soviet socialist state transformed Lithuanian women's values, beliefs, and identities and argues that women's private lives were shot through with internalized Soviet ideology, which encouraged women to be educated, socially and professionally active as well as loving and caring wives, housewives, sex objects, and mothers in equal measure (Leinartè, 2010). Other studies suggest that women in Lithuanian society were (and largely still are) often reduced to inferior status. Solveiga Daugirdaite claims that:

Although Soviet women heard a steady stream of rhetoric about equal rights, in reality they were oppressed by mandatory participation in a labour market where they did the least qualified and most poorly paid jobs, while shouldering responsibility for the family's material and spiritual well-being.

[Daugirdaitè, 2011a: 115]

Above all, Soviet women's lives have been significantly tainted by the general climate of devastating misogyny. For 
example, Daugirdaitè quotes a famous Lithuanian female poet saying that she always felt:

A certain hostility [...] not exactly conscious, but unconscious and unperceived, stemming from ancient ideas about the old lady who writes or creates in some other way, the lady whose real place is in the kitchen and bed.

[Daugirdaitè, 2011b: 191]

Considering traumatizing Lithuanian history, and the limited and unsavoury set of gender roles available to Lithuanian women, it seems hardly surprising that many, epitomized by Staponkute's silent mother, actively wanted to escape it in order to have a different life from that of their mothers, to opt for a better and emotionally more fulfilling life, if not for themselves then at least possibly for their children. Seen in this light, the mother's silence in her native Lithuanian, sacrificing her children to the place-cannibal "which gradually replaces the mother and [...] welcomes its new 'pupil"' (Staponkutè, 2009a), even if it comes at a tremendous personal loss, can be explained by her wish to distance both herself and her children from her native language-place which is marked by repression, suffering and mourning. The costly compromises it involves - the fact that she should feel alienated from her children or be entirely dependent on her husband as a result of her choice - does not cancel her intention and its fulfilment. However, my question as to why she remains silent also in the new language remains unanswered. One also thinks about many examples of mothers, who distance themselves from their native language altogether in order to break free from painful and/or traumatic experiences associated with and lived through in that language medium and opt for using exclusively the language of the host country to communicate with their children (Pavlenko, 2005). I shall come back to this at the end of the article.

\section{Obtaining a voice}

At the beginning of the essay, Staponkute introduces her alter-ego-narrator as "a migrant, a multilingual mother, and a person who wanders across cultural spaces" (Staponkutè, 2009a). She is not the monolingual silent mother faced with her multilingual children that Staponkute goes on to portray. It is therefore justified to consider that the narrator better corresponds to the reality of the majority of migrant mothers, who are neither silent nor mute. Rather, they are multilingual and enjoy the luxury of being able to switch between languages in many walks of life, including mothering.

The narrator in Staponkute's text claims that, in order to withstand the lethal silence, a migrant mother needs to appropriate the new place and "obtain a voice". She believes that a partial cure for the trauma inflicted by the foreign language that severs the bond between the mother and her children lies in learning the language of the children - learning and appropriating it, playing with it, embodying and inhabiting it, making it her own, inventing a new personality for herself in that language - and thus accepting to become a different woman and mother than she is or would be solely in her native tongue. Staponkutè writes:

To be able to see oneself as an integral part, let us say, of a system of symbols, let's call it place, and to create your own space within it, to infuse it with life and defend it with the zeal of a romantic anarchist is perhaps the only way of reducing this pain of motherhood and of avoiding silence, so that one might obtain a voice.

[Staponkutè, 2009a]

Staponkutè's multilingual mother has been severed from her own mother-language-place by the traumatic experience of the foreign language between her and her children that partially replaced her, welcomed, socialized and systematically nurtured them into the linguistic beings that they are. To insert herself back into the equation through a complicated double edged linguistic act, in order to escape the fate of the silent mother is the multilingual mother's last resort. To this end, first, she needs to acquire the language of the new place and through it get access to the history and the body of that place. In short, she must gain a degree of belonging in the new place and feed on its linguistic source of sustenance. Second, by speaking her native language to her children, in order to artificially set up her own chora-like space within that new belonging and having infused it with life, transform it from a dead into a living thing. The only way to achieve this, the narrator believes, is to translate:

I see that the only possible way out of this confusion lies not in a negation of language, but in shuttle translation. Translation is something that's not limited to linguistic technique; it absorbs the entire body, and even more than that - it requires a historical approach to the body [...] conceiving oneself as a product of history, translating from outside to inside, and from inside to outside.

[Staponkutè, 2009a]

Shuttle translation is a term that Staponkutè borrows from Gayatri Chakravorty Spivak, who defines it as part of a process of subject formation that consists of coding elements of the outside with components that are being integrated from the outside to the inside that is still indistinguishable from the outside by going back and forth (Spivak, 2000). Having used this idea as a springboard, Staponkute fills it with her own meaning. To her, shuttle translation is a form of play with language that requires embodied linguistic competence in at least two languages and is evocative of the "fort-da" game as described by Freud and reinterpreted by Caruth. As such, it suggests a way out of what I have earlier identified as the silent mother's symptoms of post-traumatic stress disorder. By re-enacting the mother's departure and thus symbolically repeating her loss, the child's game creates something new which, Caruth says, "bears witness to and breaks from the death drive, that bears witness and repeats by precisely breaking away" (Caruth, 1995: 13). In the same way, shuttle translation is not abandoning one language for the other but, rather, creating a life-affirming bridge between the two, drawing on the pre-discursive, pre-linguistic knowledge of the native tongue or, to use Spivak's terminology, coding the outside so that it becomes part of the inside too. The process of making a foreign language part of the inside may be seen as what Pavlenko classifies as an embodied competence of a language, which is characterized by a sensory and physiological response to words and structures of that language. It is usually attributed to languages learnt in childhood and in 
natural social environments (Pavlenko, 2005). In this way, speaking the new language to the children (seeing oneself as an integral part of a system of symbols or a place), but knowing that her own native language is intact and that she can speak to them in it (creating her own space and infusing it with life), becomes what Caruth calls bearing witness to the mother's trauma. It constantly repeats her separation from her children by the foreign language, but in the way that eases the pain, takes the mother away from the loss of her native mother-language-place and opens up some space for a different pre-linguistic, pre-discursive and sensual bond between her and her children to develop. The element of the new language that the mother can share with her children has a soothing if not healing effect on her.

According to Caruth, the repetitive game of the child in Freud's essay not only symbolically fulfils his wish of the mother's return, but also substitutes for the pain of loss through a creative act of life, which, in the case of the multilingual mother's shuttle translation, is a linguistic game that involves a constant mental motion between the inside (the space of the native language) and the outside (the external foreign place and language). Shuttle translation, the mother's ability to travel from one language to another in her head represents a symbolic fulfilment of her desire to mother in her mother tongue, and substitutes for the pain of the inability to do so. However, her competence in the new language provides her with the vehicle to depart at least partly or temporarily from the pain and both preceding traumas, the one to do with her national heritage and the one brought about by the foreign language. To quote Caruth: "It is a language of departure, that is, that does not repeat the unconscious origin of life as death, but creates a history by precisely departing toward survival" (Caruth, 2001: 13). The language of departure has something childlike and playful about it. According to Staponkute, "if [the multilingual mother] wants to keep pace with her offspring in a foreign linguistic environment, she has no choice but to become a child herself - spry, receptive, and tomboyish" (Staponkutè, 2009a).

Kristeva's notion of the chora originates in her theory of semiotic disposition in which pleasure plays a crucial role. To her, the semiotic disposition is the dimension of language directly linked with play, pleasure and desire:

Identifying the semiotic disposition means in fact identifying the shift in the speaking subject, his capacity for renewing the order in which he is inescapably caught up; and that capacity is, for the subject, the capacity for enjoyment.

[Kristeva, 1986: 29]

In other words, for Kristeva, the shift in the speaking subject means opening up to, or connecting with, the embodied experience of language. This fundamental linguistic capacity for playfulness and pleasure is what provides the multilingual mother with the potential of the language of departure, which in Staponkutè's text is Greek. However, the multilingual mother comes across here as concerned with maintaining her unaltered linguistic and, by extension, cultural identity and even protecting it from outside menaces ("create your own space within it, to infuse it with life and defend it"), but equally, accepting the challenge of jumping over the linguistic chasm to the children's linguistic space, in order to share the gift of her native tongue with them over there.

The silent, as opposed to the multilingual, mother would not use this potential: she would not play, speak, witness or translate. She remains resolutely dumb, stranded in the no man's land in which she is separated from both her native and adoptive place and language, from her children, her husband and herself. I would suggest that she is turned into stone by the Lithuanian national discourse of motherhood as well as the role of the mother in the Lithuanian cultural imagination that puts the mother in charge of safeguarding the native language. There are two indirect references to it in Staponkutè's essay. The first is the sentence: "by allowing a foreign language to exist between her and her child, she is doomed to a stony silence", which somehow blames the mother for letting the foreign language slip between her and her child and makes her deserving of the pain she is feeling. The second comes at the end: "As I observe the agonia (the battle of the death) of my native language on my children's lips, I behold the image of my own vanishing..." (Staponkutè, 2009a).

As it has already been pointed out, the legitimacy of the Lithuanian state has always been in question. With the Lithuanian National movement resulting in the establishment of the Lithuanian national state in 1918, the Lithuanian language became a powerful symbol of resistance and served as one during the Soviet times. Traditionally, the weight of transmitting and teaching Lithuanian is associated with mothers. At the end of the nineteenth century when Lithuania was part of Tsarist Russia and printed matter in Latin script was forbidden, it was the mother's role to ensure the maintenance of Lithuanian and thus quietly nurture resistance at home. The idea of the mother as a guarantor of the perpetuation of the Lithuanian language is perfectly immortalized in the sculpture by Petras Rimša entitled Lithuanian School 1864-1904 (Fig. 1), which portrays a mother sitting at her spinning wheel with a reading child next to her. She is leaning over the book, pointing at it, giving instructions. It is an iconic image that every Lithuanian child comes to associate with linguistic resistance to russification. The sculpture is based on historic reality as from 1864 to 1904 , whilst Lithuania was under the control of the Russian Empire, the Tsar put a ban on all Lithuanian language publications printed in the Latin alphabet within the Russian Empire. During the years of the Lithuanian press ban, mothers would teach their children to read in Lithuanian and would be able to quickly hide the book in the wool basket or under their skirts, should Tsarist soldiers come in.

The idea of the mother as a guarantor of the perpetuation of the Lithuanian language is intrinsically linked with the idea of statehood and profound insecurities in the Lithuanian psyche to do with the fear of losing it, which in turn is associated with the fear of change of regime, violence, and trauma that ensue. For the silent mother, then, to leave her native language and swap it for a foreign one would be a suicidal act of betrayal of not only her own role as a Lithuanian mother, but of the entire nation. Unable to pass on her language along with her history and heritage, she contains it safely within herself. Having chosen a different path on a personal level, she is held back, "turned into stone" by the power of the collective punitive imagination of one traumatized nation, which affects many Lithuanian women, including the educated, intelligent, spry 


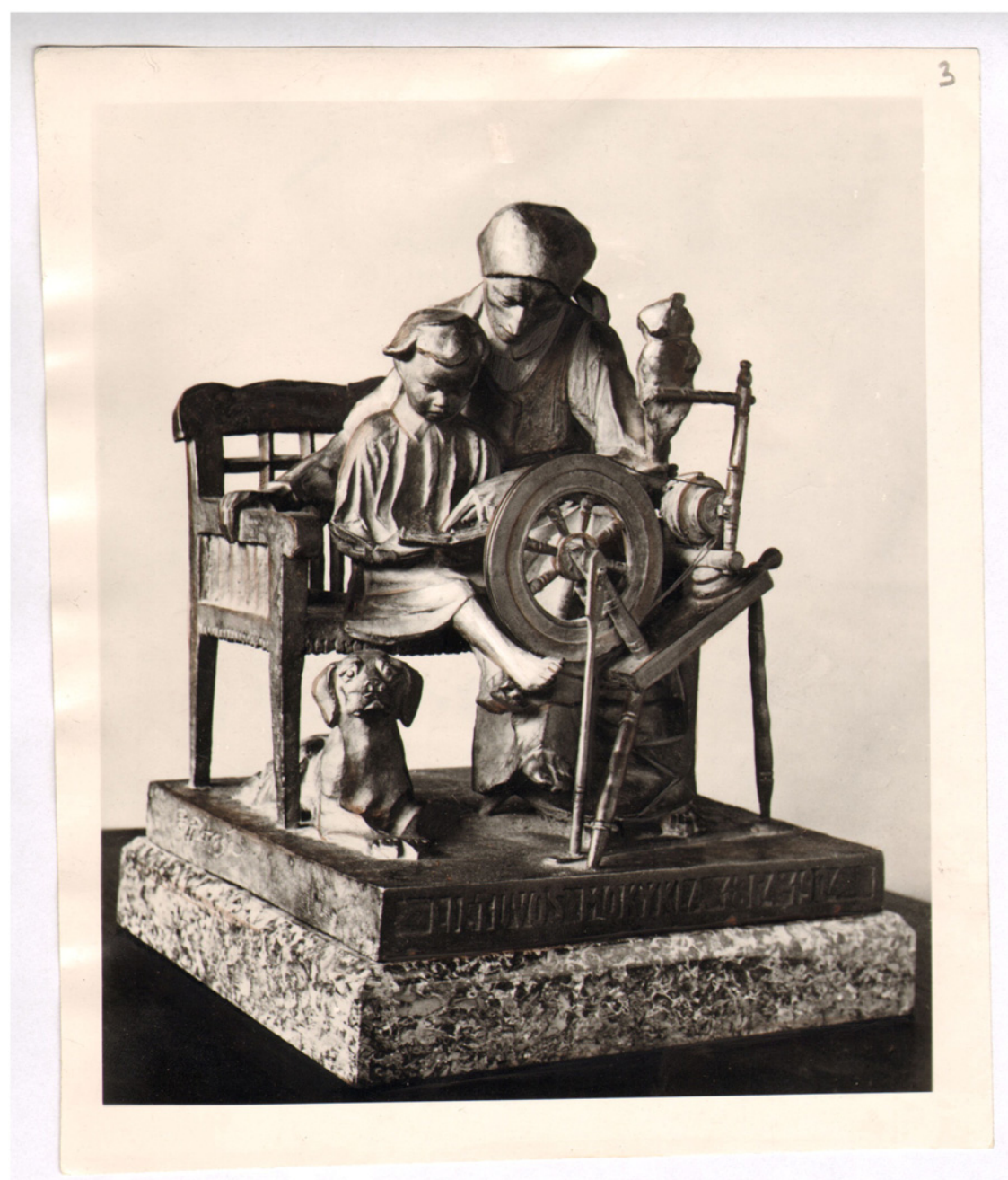

Fig. 1. Petras Rimša Lithuanian School 1864-1904.

Photograph courtesy of the Lithuanian National Martynas Mažvydas Library, Department of Rare Books and Manuscripts. LNMMB_RKRS_F47-432_L.3.jpg

and tomboyish multilingual mothers who master foreign languages of their host countries and husbands.

\section{Conclusion}

The curious and complex figure of the silent mother featured in Dalia Staponkutè's essay The Silence of the Mothers is a product of a traumatizing history and the gender regime unfavourable to women. It is also portrayed as belonging to the context of post-Soviet Lithuania, in which historically and culturally mothers have been expected to pass on their native tongue to the next generation in order to ensure the survival of the Lithuanian language, nation and, by default, state that struggled against Russian and Soviet domination for centuries. The figure of the multilingual mother featured in the essay is also affected by the Lithuanian cultural heritage and partly traumatized by the linguistic distance between her and her children. However, it offers a positive strategy to deal with the painful situation. This includes learning the language of the host country and using it to talk to the children as well as in the native tongue. The process which Staponkute calls "shuttle translation" consists of drawing on the bodily knowledge of the mother tongue in order to make the new language her own and to sustain the essential link with the children. All of this suggests that migrant and exile mothers can be heavily influenced by the motherhood culture of the native countries and use the command of the new language not only as a means to integrate in the new country, but also as an instrument to develop a sustained bond with their children.

\section{Acknowledgements}

I should like to thank the Lithuanian Research Council (No. VP1-3.1-ŠMM-01-V-02-004) for funding research that permitted the writing of this article; Prof. Gill Rye, Dr. Adalgisa Giorgio and the Motherhood in Post-1968 European Literature Network for providing the platform for it; Prof. Gill Rye for much needed and exceedingly appreciated support over the years; Prof. Dalia Leinartè and Vilnius University Gender Studies' Centre for hosting this research project and the editors of the journal for their insightful comments. 


\section{Endnotes} ${ }^{1}$ Permanent address: Tuskulenų 24-35, Vilnius LT-09211, Lithuania.
2 Staponkutè's autobiographical non-fiction book Iš dviejų renkuosi trečiqa:
Mano mažoji odisejja [The Third Country: My Little Odyssey], published in
December 2014 in Vilnius, is another such example exploring her experience of
living, bringing up children, working and pursuing a career between two
cultures and languages. It raises issues of multiple belongings and feelings of
estrangement (Staponkute, 2014b).
${ }^{3}$ The genre originates with Michel de Montaigne's Essais that "lie
awkwardly across the divide between imaginative literature and intellectual
reflection" (Kay, Cave and Bowie, 2006: 135). For more on the historical context
and the development of the genre in Lithuania, see my book review (Kačkutè,
2014).

${ }^{4}$ Private correspondence with Staponkute by e-mail and live conversations during her visit to Switzerland in January 2015 during which she presented her latest book to the Swiss Lithuanian community.

${ }^{5}$ It is interesting to note that, in her own translation of the essay, which is otherwise quite similar to that by Darius Ross, Staponkute translates the title as The Mothers' Silence (Staponkute, 2009b), as if referring to her own silence in relation to her children - in her second book she writes of her own experience as a silent mother during family conversations in Greek. Following Staponkutè's recommendation, all quotations in this article, including a more accurate translation of the title, come from Darius Ross's translation (Staponkute 2009a). The quotations come from the unpaginated online version.

${ }^{6}$ In 2011 two conferences were held in Lithuania - one at the Lithuanian University of Educational Sciences, entitled "Axiological Identity Aspect in Contemporary Lithuanian Exile Literature" and the other at Vytautas Magnus University, entitled "Exiled Identity in Literature".

${ }^{7}$ Satkauskyte uses the term "literature of migration" or "migration literature" in order to make a distinction between contemporary post-Soviet, post-1989 migration and Lithuanian exiles who emigrated during WWII. Among them, there were many writers and poets who continued writing and publishing in Lithuanian despite the lack of Lithuanian readership. Feelings of nostalgia and longing for their lost home, homeland and language are the main themes of their creative output.

${ }^{8}$ This idea is further developed in Staponkutè's latest book (see note 2), in which she suggests several potential embodiments of the third space, the locus of belonging: travelling, being on the move as well as language(s), writing and literature.

${ }^{9}$ Translation from Lithuanian mine.

${ }^{10}$ The Greek husband here and throughout Staponkute's essay is slightly confusing, because the author herself is married to a Greek Cypriot rather than a Greek man and lives in Cyprus, rather than in Greece. However, in The Silence of the Mothers she writes: "Continuously plying the same route, LithuaniaGreece-Cyprus, I meet dozens, no, hundreds of Lithuanian girls who have become the wives of foreign men and the mothers of their children, and who have never really spoken any other language than their mother tongue" (Staponkute, 2009a). The couple she goes on to write about is probably based on a real life Greek-Lithuanian couple she once met on her way to or from Lithuania via Athens. The conflation of Greek and Cypriot husbands and comparability of their Lithuanian wives in the essay suggests that Staponkute sees the figure of the silent mother as, first, a post-Soviet Lithuanian marriage exile irrespective of the nationality of the husband and, second, as universal. Reading the text through the lens of Cyprus's postcolonial and recent history the influence of the British colonial power, the division, including the linguistic division of the country and traditional patriarchal gender culture - may be interesting and fruitful but beyond the scope of this article.

${ }^{11}$ At the time of writing The Silence of the Mothers Staponkute was indirectly influenced by Julia Kristeva's work through Ruth Salvaggio's reading of the "oral forces at play in Kristeva's notion of the 'semiotic disposition' of language" (Salvaggio, 1998: 22), in which she interprets the presence of the semiotic disposition including the workings of the chora in language as the maternal and more embodied dimension of language, which is associated with enhanced creativity and its positively transformative powers.
Baločkaitè, Rasa (2009). "Go West..." myths of femininity and feminist utopias in East and West. (http://www.eurozine.com/articles/2009-08-14balockaite-en.html, consulted 25/09/2014).

Bhabha, Homi (2004). The location of culture (Classics Edition). London, New York: Routledge.

Butler, Judith (1990). Gender trouble: Feminism and the subversion of identity. New York: Routledge.

Caruth, Cathy (1995). Trauma. Explorations in memory. Baltimore, London: The Johns Hopkins University Press.

Caruth, Cathy (2001). Parting words: Trauma, silence and survival. Cultural Values, 5(1), 7-27.

Chioni Moore, David (2006). Is the post- in postcolonial the post- in postSoviet? Towards a global postcolonial critique. In V. Kelertas (Ed.), Baltic postcolonialism (pp. 11-45). Amsterdam. New York: Rodopi.

Čiočytė, Dalia (2011). Lithuanian essay: Between the Soviet era and independence. In M. Kvietkauskas (Ed.), Transitions of Lithuanian postmodernism (pp. 177-200). Vilnius: Institute of Lithuanian Literature and Folklore.

Daugirdaite, Solveiga (2011a). The "second wave" of women's literature. In E. Baliutytè, \& D. Mitaitè (Eds.), Baltic memory (pp. 113-124). Vilnius: Institute of Lithuanian Literature and Folklore.

Daugirdaite, Solveiga (2011b). Women's literature and its readings. In M. Kvietkauskas (Ed.), Transitions of Lithuanian postmodernism (pp. 177-200). Vilnius: Institute of Lithuanian Literature and Folklore.

Davoliūte, Violeta, \& Balkelis, T. (2012). Maps of memory: Trauma, identity and exile in deportation memoirs from the Baltic States. Vilnius: Institute of Lithuanian Literature and Folklore.

Gailienė, Danutė (2008). Ka jie mums padaré. Vilnius: Tyto Alba.

Kačkutė, Eglè (2014). Turning life into credible fiction. Lituanus, 60(4), 87-93.

Kay, Sarah, Cave, Terence, \& Bowie, Malcolm (2006). A short history of French literature. Oxford: Oxford University Press.

Kelertas, Violeta (2006). Baltic postcolonialism. Amsterdam, New York: Rodopi.

Kiaupa, Zigmantas (2002). The history of Lithuania. Vilnius: Baltos Lankos.

Kolevinskienė, Žydronė (2012). Šiuolaikinès lietuvių prozos spindesys ir skurdas. Gimtasis žodis, 12, 21-29.

Kristeva, Julia (1980). Desire in language: A semiotic approach to literature and art. Oxford: Basil Blackwell.

Kristeva, Julia (1984). Revolution in poetic language. New York: Columbia University Press.

Kristeva, Julia (1986). The system and the speaking subject. In Toril Moi (Ed.), The Kristeva reader (pp. 25-33). New York: Columbia University Press.

Leinartè, Dalia (2010). Adopting and remembering Soviet reality: Life stories of Lithuanian women, 1945-1970. Amsterdam: Rodopi.

Litvinskaitè, Dalia (2013). Nuo objekto link subjekto: Kūnas lietuviu moteru kūryboje. Vilnius: Lietuvių literatūros ir tautosakos institutas.

Lorber, Judith (1994). Paradoxes of gender. London: Yale University Press.

Moslund, Sten Pultz (2010). Migration literature and hybridity: The different speeds of transcultural. Palgrave: Macmillan.

Pavlenko, Aneta (2005). Emotions and multilingulism. Cambridge: Cambridge University Press.

Pavlenko, Aneta (2008). Multilingualism in post-Soviet countries. Clevedon: Multilingual Matters.

Salvaggio, Ruth (1998). The sounds of feminist theory. Albany, NY: State University of New York Press.

Satkauskytè, Dalia (2011). Egzilinè (ne)tapatybė naujausioje lietuviu emigrantų literatūroje. Oikos, 2(12), 120-129.

Spivak, Gayatri Chakravorty (2000). Translation as culture. Parallax, 6(1), $13-24$.

Staponkutè, Dalia (2007). Lietumi prieš saulę. Vilnius: Apostrofa.

Staponkute, Dalia (2009a). The silence of the mothers. Excerpta Cypriana, 6(3), (http://iwp.uiowa.edu/91st/vol6-num3/the-silence-of-the-mothers, translated by Darius Ross, consulted 25/09/2014).

Staponkutè, Dalia (2009b). The mothers' silence. Lituanus, 55(1), 39-45 (online version http://www.lituanus.org/2009/09_1_02\%20Staponkute.htm, translated by Dalia Staponkute, consulted 25/09/2014).

Staponkute, Dalia (2014a). Exultant forces of translation and the philosophy of travel of Alphonso Lingis. New York: Nova Publishers.

Staponkutė, Dalia (2014b). Iš dvieju renkuosi trečiq. Vilnius: Apostrofa.

\section{References}

Baločkaite, Rasa (2008). Between mimesis and non-existence. (http://www. eurozine.com/articles/2008-05-08-balockaite-en.html, consulted 25/09/ 2014). 